\title{
Knowledge, attitude and practice of adults to the national health insurance scheme (NHIS) in Unguwar Soya, Kabong Ward of Jos North LGA, Plateau State-Nigeria
}

\author{
Amos Paul Bassi ${ }^{1}$, Ebenezer Chinomnso Anthony 2, ${ }^{*}$, Bukunmi Tejumade Adediran ${ }^{3}$, Jemima Abner ${ }^{4}$, \\ Solomon Mallum Anyakwai Thliza ${ }^{5}$ and Chris Anyanechi 6
}

\author{
${ }^{1}$ Department of Community Medicine and Primary Health Care, College of Medicine and Health Sciences, Bingham \\ University, Jos Campus, Nigeria. \\ 2 Department of surgery, Bingham University Teaching Hospital, Jos Nigeria. \\ ${ }^{3}$ Department of Internal Medicine, University College Hospital, Ibadan Nigeria. \\ ${ }^{4}$ Department of Surgery, State Specialist Hospital, Gombe Nigeria. \\ ${ }^{5}$ State Specialist Hospital Maiduguri, Borno State, Nigeria. \\ ${ }^{6}$ Department of Internal Medicine, Federal Medical Center, Umuahia Nigeria.
}

GSC Biological and Pharmaceutical Sciences, 2021, 16(01), 239-250

Publication history: Received on 20 June 2021; revised on 27 July 2021; accepted on 29 July 2021

Article DOI: https://doi.org/10.30574/gscbps.2021.16.1.0209

\begin{abstract}
Health, according to the World Health Organization is defined as a state of complete physical, mental, social and spiritual wellbeing, and not merely the absence of disease or infirmity. This was a cross sectional community based descriptive study using a multi stage sampling technique in Unguwar Soya Community, Kabong, Jos North LGA, Plateau State, Nigeria with the aim of assessing and establishing the knowledge, attitude and practice of the residents to NHIS. An interviewer administered structured questionnaire was utilized and a total of 252 questionnaires were administered to the eligible members of the community. Majority of the Respondents are aged 20-29 years (33.7\%). Majority of the respondents were females (63.5\%), largely married (54.0\%), most have attended secondary level of education (47.2\%) and are mostly Artisans (32.1\%) with majority earning above 30,000 naira (25.8\%).59.5\% of the respondents had heard about NHIIS; family and friends were the most common sources of NHIS awareness (25.5\%). Majority of the respondents (49.3\%) had heard about NHIS more than five years ago. Majority of the respondents (70.7\%) had good attitude towards NHIS. Only $13.3 \%$ of the respondents are registered with NHIS. $88.5 \%$ of the respondents fund their health expenditures through Out-of-pocket payment. Results depicted that the index population has inadequate awareness and knowledge of the National Health Insurance Scheme. Resulting in the small portion of the population participating in the scheme. The government can come to the aid of this community and other communities by providing adequate awareness, knowledge and privilege to participate in the scheme to better their health.
\end{abstract}

Keywords: Index population; Participation; NHIS; Community; Awareness

\section{Introduction}

Health, according to the world Health Organization (WHO) is defined as a state of complete physical, mental, social and spiritual wellbeing, and not merely the absence of disease or infirmity. It is one of the most important indices of the wealth and prosperity of any nation, Nigeria inclusive [1]. Good health is desirable by every well-meaning Nigerian. It not only contributes to better quality of life but is also absolutely essential for a virile labour force for the creation and maintenance of a nation's wealth $[2,3]$. Sadly however, the healthcare system in Nigeria has not been very sufficient in meeting the health needs of Nigerians since many Nigerians still are unable to access the best of health care for various

\footnotetext{
* Corresponding author: Ebenezer Chinomnso; E-mail: anthonyec92@gmail.com

Department of Surgery, Bingham University Teaching Hospital, Jos Nigeria. 
reasons, finance constituting a major factor. In 2005, in a study done by the World Health Organization, United Nation, Nigeria's health system was still performing below average even by sub-Saharan standards and was ranked $197^{\text {th }}$ out of the 200 member states [4]. One of the well-established impediments to the health care service of Nigeria include accessibility and coverage [5]. Access to healthcare is severely limited in Nigeria, [6] and has been fraught with some difficulties in terms of financing and cost of billing for the services received. Consequently, like many public services, it is not equally accessible to all people [7] and so, limited physical access to basic health care continues to be a major impediment to achieving the goal of health care for all [8]. Against this background, nations and states have developed robust mechanisms to provide social health security for her members in order to protect them from financial hazards and encourage better health seeking behavior [9]. This social security against unexpected eventuality of illness, and its consequent impact on health dynamics is known as Health Insurance. An insurance system is aimed to give citizens support against the economic consequences of illness as well as disablement, childbirth, old age and death [10]. Health insurance originated in Europe in the early 1800s when mutual benefit societies arose to lighten the financial burden for those stricken with illness. Insurance is a way of pooling and distributing risk [9]. Today, Health Financing is a term used to include all ways that health care services are funded, insurance included. Healthcare financing refers to the ways and means, by which money is raised to fund health activities, as well as how it is used (that is the allocation of the funds). General revenue/Public budget, Dedicated tax, Out-of-pocket - at the point of enjoyment of service, Social Health Insurance, Private Health Insurance, community-based health expenditure, Loans and Grants - Subsidy from development partners and donor nations and Charity $[11,12,13]$. The National Health Insurance Scheme in Nigeria, even though had precedence from even the military, was established under Act 35 of 1999 [14] but took off in 2005 after the NHIS Act, Cap42, Laws of the Federation of Nigeria, 2004 [15]. In addition to being the $187^{\text {th }}$ of 191 countries in terms of health service, Nigeria's health indices are discouraging. Prenatal Mortality Rate is estimated to be 48 per 1000; Infant Mortality Rate range between 500 per 100,000 in the South-West geopolitical zone to 800 per 100,000 infants in the North-East geopolitical zone. Child Mortality Rate is about 205 per 1000 (UNICEF, 2006) [16]. Under-5 Mortality Rate in 2013 ranged between 100 - 150 per 1000 live births $[17,18]$ with states in Nigeria as high as 100 250 per 1000 live births [18]. Maternal Mortality Ratio for Nigeria are as high as 814 per 100,000 live births according to the 2016 World Health Statistics [19], making Nigeria the country with the $4^{\text {th }}$ worst Maternal Mortality. National Health Insurance Scheme (NHIS) as the Social Insurance Scheme of Nigeria covers $<10 \%$ of the Nigerian Populations [20], some studies put it at about 3\% [21], which means that the most (vulnerable) of Nigerians are without any social and financial risk protection. Out-of-pocket payments for health care services limit the poor from accessing and utilizing basic healthcare services $[22,23,24,25]$. The legislation that established the NHIS is known as "The National Health Insurance Scheme (NHIS) Decree No. 35 of 1999, Laws of the Federation of Nigeria" was signed into law on May 10, 1999. It is divided into Parts I - IX (The Establishment of the National Health Insurance Scheme, etc.), II (Objectives, functions and powers of the scheme), III (Staff of the scheme), IV (Financial Provisions), V (Contributions), etc. [26]. In Lagos State, Nigeria, 2016, a study "National Health Insurance Scheme (NHIS): Are the Artisans benefitting in Lagos State, Nigeria?" was carried out by Campbell P.C et al. it was carried out using interviewer-administered questionnaires and as a descriptive cross-sectional survey amongst 260 artisans who participated to determine the "knowledge, attitude, uptake of and willingness to enroll in the National Health Insurance Scheme among the artisans". Majority of the respondents, i.e., 226 (86.9\%) were not aware of HI. The overall knowledge was poor (6.5\%) and the main source of information was through radio/television (41.2\%). Nearly, half of the respondents (33 out of 67) identified the concept of HI as a pool of contributors' fund for only healthcare service. A high proportion of the respondents (27 out of 34) were aware of the benefits of HI, although majority, i.e., 27 (79.4\%) identified access to medication as the benefit. The majority of the respondents, i.e., 228 (87.7\%) expressed negative attitude toward the scheme; however, $76.5 \%$ were willing to join the HI scheme. Low awareness/poor knowledge translated to negative attitude [27]. The need for an aggressive stakeholders' enlightenment campaign for increasing coverage was identified by researchers. A study (cross-sectional descriptive) conducted in 2012 in Jos, Nigeria "An evaluation of the national health insurance scheme (NHIS) in Jos, a north-central Nigerian city" by Onyedibe K.I, findings show that only $24 \%$ of adults were enrolled in the scheme. Notably, $82 \%$ of enrolled respondents were aware of NHIS and prefer it to the fee for service system. There was some level of dissatisfaction in the scheme (26\% of enrollees) [28].

Most Nigerians seek intervention when sick, in order to maintain health or to restore it. This study seeks to establish scientifically the knowledge, attitude and practice of National Health Insurance Scheme (NHIS) using a sample population within the Jos North Local Government Area of Plateau State, Nigeria.

\section{Material and methods}

This is a cross sectional descriptive survey, to at a glance appreciate the National Health Insurance Scheme (NHIS) uptake in Jos North, Plateau state [29]. Two hundred and fifty- two questionnaires (252) were administered to eligible and willing respondents in Unguwar Soya area at the time of the study in September, 2019. 


\subsection{Study Design}

There are four hundred and fifty households in the area and systematic sampling technique was employed to enter $20 \%$ of the households.

This is a cross-sectional descriptive study of households over a period of 3 months (September 2019 - November 2019).

\subsection{Study Site}

Unguwar Soya community/settlement of the Kabong Ward of Jos North LGA, Jos, and Plateau State is the area of interest for study, and was selected following a multi-stage sampling process. Jos North is one of the seventeen Local Government Areas in Plateau State. It is situated in the Jos township city centre9 ${ }^{\circ} 55^{\prime} \mathrm{N} 8^{\circ} 54 \mathrm{E}$. It has an area of $291 \mathrm{~km}^{2}$ and a population of 429,300 at the 2006 census with 266,660 (62\%) being urban dwellers and 163,134 (38\%) rural dwellers [30]. Unguwar Soya is a densely populated semi-urban settlement under Kabong (Tudun Wada) ward in Jos North LGA of Plateau state. Its populace is mainly of low and medium literacy levels and socio-economic status. They are a mixed community, made up of people from different ethnic groups both within and outside Plateau state.

\subsection{Sampling method/Instrument of data collection}

A multi-stage sampling technique/process was used. Data will be collected using a structured interviewer administered questionnaire, formulated based on the objectives of the study, adapted from the work of Ekwuluo et al., [31].

\subsection{Statistical analysis}

The Data collected will be entered and analyzed using the SSPS version 20 computer software. Significant relationship and associations will be determined using the chi square $\left(\mathrm{X}^{2}\right)$ test. Associations will be drawn for complications and risk factors with a $\mathrm{P}$ value of $\leq 0.05$ will be taken as statistically significant. Tables and charts were appropriately used.

\section{Results and discussion}

Two hundred and fifty-two adults between the ages of 18years and greater than 60 years (76years) were interviewed (Table 1). The mean age was 34.6 years. Most of the adults are within the ages of 20-29 years, followed by those within the age group of 30-39 years which corresponds with the Nigeria Demographic survey of 2013 which indicates that Nigeria's population is young, a scenario typical of countries with high fertility rate. About half (47.2\%) of the population have attained secondary level of education with about one third (31.7\%) of the population attaining post-secondary level of education and about $5.2 \%$ of the population have no form of formal education - Table 1, which does not correspond with the Nigeria Demographic survey of 2013 that states that the percentage of men with no education ranges from 1 percent or lower in many states [32]. Majority of the population are artisans accounting for about 32.1\%, followed by those unemployed accounting for $27.4 \%$ (which corresponds with $21.2 \%$ of urban dwellers that are unemployed as reported in the Labour force statistics [33]) and then about $7.5 \%$ are civil servants (Table 1). Our study showed that $58.4 \%$ of the population earns less than 19,999 - Table 2, which correspond with the 2006 annual collaborative survey of socio-economic activities in Nigeria which had about $61.8 \%$ of people earning below 19,999 at the national level, and about $25.8 \%$ of the population earn above 30,000 . In terms of marital status, our study showed that $54 \%$ of the population were married while $46 \%$ were unmarried (Table 1). This has a similar pattern with the 2006 annual collaborative survey of socio-economic activities in Nigeria which had about $56.1 \%$ of those married and about $35.5 \%$ who were never married [34].

Table 1 Socio-demographic outlay of the respondents in Unguwar soya

\begin{tabular}{|c|c|}
\hline Socio-demographics $(n=252)$ & Descriptive analysis \\
\hline \multicolumn{2}{|l|}{ Age classification Number (\%) } \\
\hline \multicolumn{2}{|l|}{$<20$ years $18(7.1 \%)$} \\
\hline \multicolumn{2}{|l|}{$20-29$ years $85(33.7 \%)$} \\
\hline $30-39$ years $81(32.1 \%)$ & mean: 34.6 \\
\hline \multicolumn{2}{|l|}{$40-49$ years $32(12.7 \%)$} \\
\hline $50-59$ years $16(6.3 \%)$ & standard deviation: 13.9 \\
\hline$>60$ years $20(7.9 \%)$ & \\
\hline
\end{tabular}




\begin{tabular}{|c|c|}
\hline \multicolumn{2}{|l|}{ Gender Number (\%) } \\
\hline Females 160 (63.5\%) & mean: 1.6 \\
\hline Males $92(36.5 \%)$ & standard deviation: 0.5 \\
\hline \multicolumn{2}{|l|}{ Marital status Number (\%) } \\
\hline Married 136(54.0\%) & mean: 1.7 \\
\hline \multicolumn{2}{|l|}{ Single $102(40.5 \%)$} \\
\hline Widowed $10(4.0 \%)$ & standard deviation: 0.9 \\
\hline \multicolumn{2}{|l|}{ Separated 3(1.2\%) } \\
\hline Divorced $1(0.4 \%)$ & \\
\hline \multicolumn{2}{|l|}{ Educational status Number (\%) } \\
\hline \multicolumn{2}{|l|}{ Secondary $119(47.2 \%)$} \\
\hline Post-secondary $80(31.7 \%)$ & mean: 4.0 \\
\hline \multicolumn{2}{|l|}{ Primary $39(15.5 \%)$} \\
\hline None $13(5.2 \%)$ & standard deviation: 1.0 \\
\hline \multicolumn{2}{|l|}{ quranic $1(0.4 \%)$} \\
\hline \multicolumn{2}{|l|}{ Occupation Number (\%) } \\
\hline \multicolumn{2}{|l|}{ Artisan $81(32.1 \%)$} \\
\hline None $69(27.4 \%)$ & mean: 3.3 \\
\hline \multicolumn{2}{|l|}{ Self-employed $42(16.7 \%)$} \\
\hline Private sector employee $29(11.5 \%)$ & standard deviation: 1.8 \\
\hline \multicolumn{2}{|l|}{ Civil servant $19(7.5 \%)$} \\
\hline \multicolumn{2}{|l|}{ Farming $8(3.2 \%)$} \\
\hline Others $4(1.6 \%)$ & \\
\hline
\end{tabular}

Table 2 Economic variables of respondents in Unguwar soya

\begin{tabular}{|c|c|}
\hline Income of respondents classified (in Naira) Number (\%) & Descriptive analysis \\
\hline Below $500039(15.5 \%)$ & \\
\hline $5000-999942(16.7 \%)$ & \\
\hline $10000-1499945(17.9 \%)$ & mean: 1.7 \\
\hline $15000-1999921(8.3 \%)$ & standard deviation:0.9 \\
\hline $20000-2499918(7.1 \%)$ & \\
\hline $25000-2999922(8.7 \%)$ & \\
\hline Above $3000065(25.8 \%)$ & \\
\hline &
\end{tabular}

\subsection{Awareness}

Following the survey done in Unguwar soya amongst respondents, it was found out that $59.5 \%$ of the respondents were aware or had heard about the National Health Insurance Scheme, while 40.5\% were unaware of the scheme (Figure 1). This reveals that a relatively larger number of residents of Unguwar soya were aware of the NHIS, compared to those who were unaware. Albeit, $40.5 \%$ is a significant percentage that is unaware of NHIS. The ratio of aware: unaware was 1.47:1, which means that out of every 1.5 persons who are aware of NHIS, there is 1 person who is unaware of the scheme. It is safe to infer that quite a significant number of the population need to be made aware of the NHIS. This is unlike a similar study conducted amongst Health Care consumers in Oyo state where as high as $87 \%$ of respondents were aware of the program [35] or in Cross River state [36] where 92.3\% respondents were aware of NHIS. 


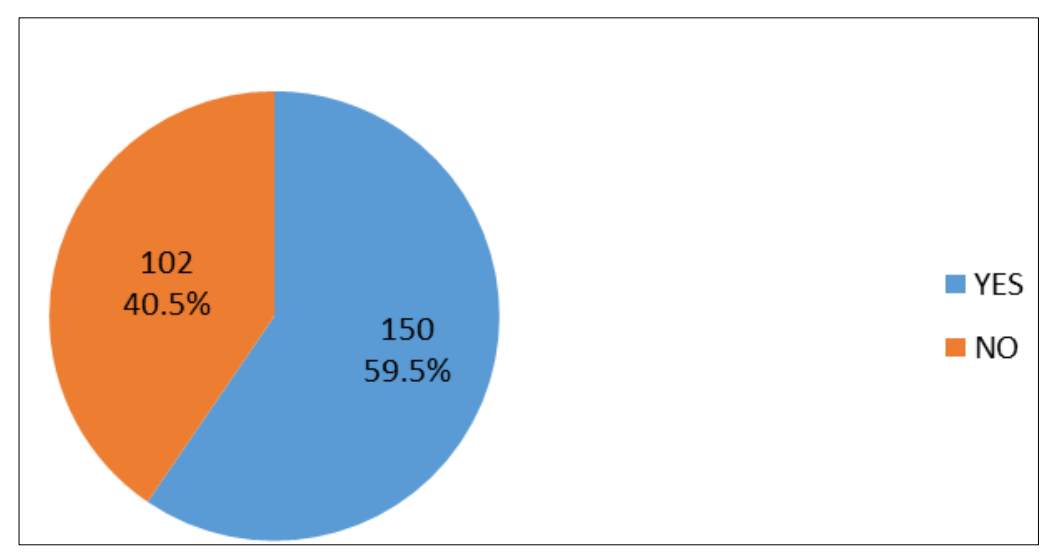

Figure 1 Awareness of respondents in Unguwar soya to the NHIS

In another study done in Osun State "Knowledge and Attitude of Civil Servants in Osun State, South-Western Nigeria towards National Health Insurance Scheme", only 40\% of respondents were aware of NHIS [37]. This is less than the percentage of aware respondents in our study. Similarly, in a 2016 study done amongst traders in Abakiliki Main Market, South-Eastern Nigeria, only $30.3 \%$ of respondents were aware of NHIS [38]. Amongst artisans in Lagos, in another study done, 86.9\% were unaware of the National Health Insurance Scheme [27]. The reason for our result, which shows an almost equal ratio of those aware to those not aware (1.5:1), compared to awareness levels of other regions, could be related to the unique socio-demographic characteristics of the residents of Unguwar soya; it being a mix of artisans and civil servants; poorly educated and well educated, hence balancing out of awareness and unawareness.

The comparatively high lack of awareness of the NHIS (40.5\%) however is unacceptable, especially for an urban setting. (Similar urban setting in Oyo had an unawareness level of only 13\%). This high level of ignorance about NHIS in our study environment could be because of poor sensitization efforts in part of government and stake-holders.

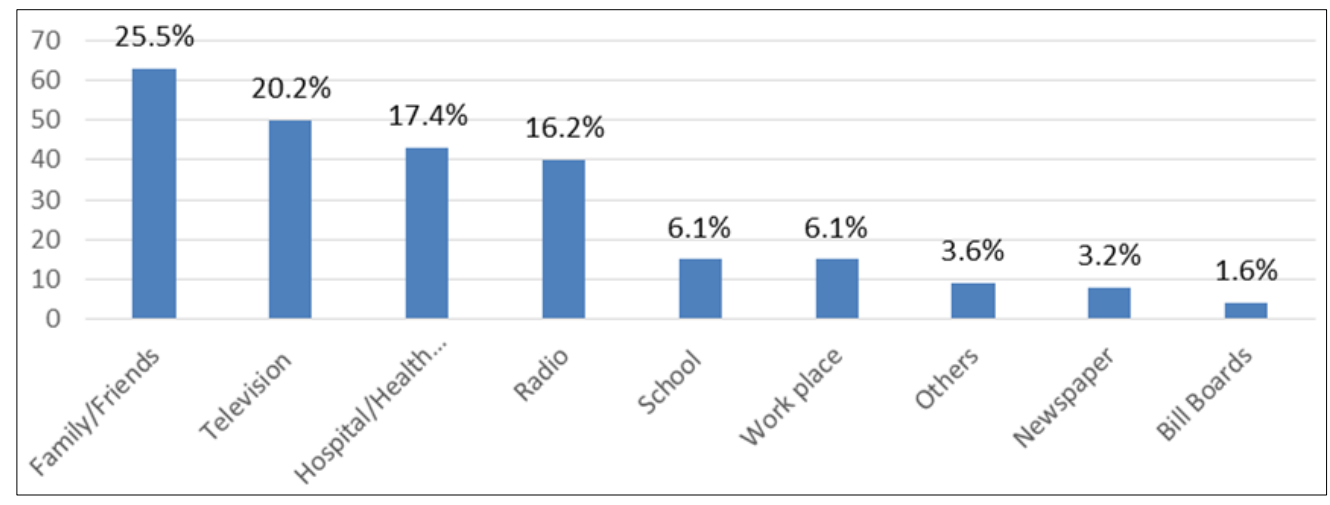

Figure 2 Sources of information gotten by respondents in Unguwar soya to the NHIS

\subsection{Multiple sources of information}

From our study, most respondents heard about NHIS from family/friends (25.5\%), television (20.2\%), hospital/health workers $(17.4 \%)$ and radio $(16.2 \%)$ respectively, while other sources with relatively smaller percentages were school (6.1\%), newspaper (3.2\%), billboards (1.6\%) and other sources such as church programmes, seminars, internet making up 3.6\% (Figure 2). However, similar studies done amongst civil servants in Osun state showed that the commonest sources of NHIS awareness were television, followed by billboards [37]; another study done among artisans in Lagos also showed that the main sources of NHIS information were radio/television (79.4\%) [27]. these are slightly different from the result in Unguwar soya that revealed family/friends as the main source of awareness, followed by television, with billboards providing for only a meagerly $1.6 \%$. In a study done in Eastern Cape, South Africa, the common sources were internet, followed by seminars/meetings, then Television and Radio, family/friends, Newspaper [38]. The result we obtained in Unguwar Soya is plausible given the communal set-up of the study area. 


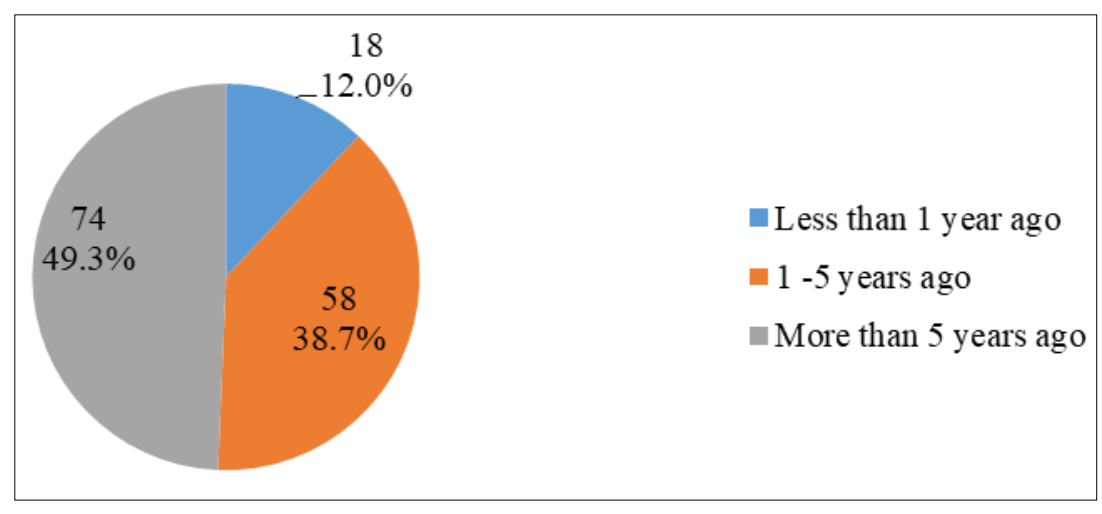

Figure 3 Duration of NHIS awareness of respondents in Unguwar soya

Majority of those who had heard about NHIS had heard about it more than 5 years ago (49.3\%), followed by those who had heard about it 1 -5 years ago (38.7\%) - Figure 3. The least percentile had heard about NHIS less than 1 year (12.0\%) - Figure 3. This could mean that awareness might have declined in the past 1 year.

Persons aged $30-39$ (36.9\%) were the most aware of NHIS, followed by those between $20-29$ (28.2\%). Those at the extremes of age had the least awareness. Our study showed that there was a significant association between age and NHIS awareness ( $p=0.022$ ) with Cramer's V value of 0.228 (Table 3). This could be explained by the fact that majority of respondents were actually young people and that they were at the age of responsibility and better exposure. Our result is in tandem with a study done in Enugu [39] which illustrated that "socio-demographic characteristics (such as age) played considerable role in the level of awareness of NHIS..." and another study done by Adibe et al which showed that middle aged persons (36 - 50years) were less likely to be aware of NHIS. Again, this is slightly similar to our study and is plausible as middle agers in a setting such as Unguwar Soya had less screen-time, in contrast to young people (20 - 39years) who had more screen time and social interactions to afford them knowledge about NHIS. From our study, it was demonstrated that there is an association between the Education and Awareness of NHIS ( $p=0.000141$ ), with Cramer's V value of 0.300 which signifies a moderately strong and Positive relationship (Table 3). This is consistent with similar studies done in Enugu that showed that highly educated respondents were "more likely to be aware" of NHIS than those less educated [39] but is in contrast to a study done in Oyo state that showed that there was no statistical relationship between educational status and awareness [35]. From our study, it is plausible that level of awareness should be associated with educational level, since higher levels of education often engenders wider exposure and social circle, and thus the higher likelihood of having heard about NHIS via multiple media. There is no significant relationship between marital status and awareness of NHIS in our study population $(p=0.609)-$ Table 3 . This is in contrast to a study done in Lagos that showed some relationship between awareness (and participation) to "educated couples" [40]. In a study done by Adibe et al [39], respondents who were married were more likely to be aware of NHIS. Another study done by Sanusi R. et al in Oyo state [35] however seemed more consistent with our findings in Unguwar Soya that "...marital status was not significant factors influencing the awareness of respondents about the program". Our result could be explained by the possibility that the sources of NHIS information in the study community were equally accessible to both married and single adults in the community. From the result of our study, there is significant association (moderately strong and positive relationship) between the occupation of respondents and awareness of NHIS ( $p=0.000492$; Cramer's $V=0.279$ ) - Table 3. This is plausible and consistent with findings in Enugu that reveals that employment was a significant factor in determining the level of awareness [39]. Again, studies in Oyo state suggest that civil servants were more likely to be aware of NHIS than artisans, farmers, traders, and unemployed counterparts [35]. Lagos state studies also reveal the likelihood of awareness increasing with occupation; and the more sociallyexposing the occupation is, the higher the likelihood [40]. One could infer that this is because educated persons are more likely to be gainfully employed and the employed are more socially exposed and have access to sources of information about NHIS.

From the results, there is no association between gender and awareness $(p=0.952)-$ Table 3. Studies in Enugu reveal otherwise as it is seen that males are more likely to be aware of NHIS than their female counterparts [39]. A study in Oyo state however revealed otherwise, and is consistent with our findings; that there is no statistical relationship between gender and awareness [35]. The result in Unguwar soya could be explained as being because both male and female are equally exposed, as in an urban setting - and privy to several sources of information about NHIS. 
Table 3 Relationship between Socio-demographic characteristics and awareness to NHIS among respondents in Unguwar soya

\begin{tabular}{|c|c|c|c|}
\hline \multirow{2}{*}{ Socio-demographic } & \multicolumn{3}{|c|}{ Awareness of NHIS } \\
\hline & Yes & No & total \\
\hline \multicolumn{4}{|l|}{ Age } \\
\hline$<20$ years & 8 & 10 & 18 \\
\hline $20-29$ years & 43 & 42 & 85 \\
\hline $30-39$ years & 55 & 26 & 81 \\
\hline $40-49$ years & 25 & 7 & 16 \\
\hline $50-59$ years & 9 & 7 & 16 \\
\hline$>60$ years & 10 & 10 & 20 \\
\hline Total & 150 & 102 & 252 \\
\hline \multicolumn{4}{|l|}{ Educational qualification } \\
\hline None & 2 & 11 & 13 \\
\hline quranic & 1 & 0 & 1 \\
\hline primary & 21 & 18 & 39 \\
\hline secondary & 64 & 55 & 119 \\
\hline post-secondary & 62 & 18 & 80 \\
\hline Total & 150 & 102 & 252 \\
\hline \multicolumn{4}{|l|}{ Marital status } \\
\hline single & 57 & 45 & 102 \\
\hline married & 85 & 51 & 136 \\
\hline divorced & 1 & 0 & 1 \\
\hline separated & 2 & 1 & 3 \\
\hline widowed & 5 & 5 & 10 \\
\hline Total & 150 & 102 & 252 \\
\hline \multicolumn{4}{|l|}{ Occupation } \\
\hline None & 35 & 34 & 69 \\
\hline Farming & 5 & 3 & 8 \\
\hline Artisan & 46 & 35 & 81 \\
\hline civil servants & 18 & 1 & 19 \\
\hline private sector employee (pse) & 22 & 7 & 29 \\
\hline self-employed & 20 & 22 & 42 \\
\hline Others & 4 & 0 & 4 \\
\hline Total & 150 & 102 & 252 \\
\hline \multicolumn{4}{|l|}{ Gender } \\
\hline Male & 57 & 37 & 93 \\
\hline Female & 94 & 65 & 159 \\
\hline Total & 150 & 102 & 252 \\
\hline
\end{tabular}

\subsection{Attitude}

Majority of the respondents (70.7\%) had a good attitude towards the National Health Insurance Scheme, $20.7 \%$ of the respondents had a fair attitude while only $8.7 \%$ had a poor attitude towards the Insurance Scheme (Figure 4). This is in keeping with a study done by Olugbenga- Bello A.I and Adebimpe W.0, 2011 which showed that most of the respondents were willing to participate in NHIS [37]; and also, by a study done by Adewole et al., 2015 which showed that majority 
of the respondents agreed that NHIS was better than Out- of-pocket payment, it minimizes financial hardship, encourages access to health care, will encourage others and that it is a good idea [41].

Table 4 Relationship between the Socio-demographics and the Attitude of the respondents in Unguwar soya

\begin{tabular}{|c|c|c|c|c|}
\hline \multicolumn{5}{|c|}{ Attitude } \\
\hline Variable & good & fair & poor & Total \\
\hline \multicolumn{5}{|c|}{ Age at last birthday (years) } \\
\hline$<20$ & 4 & 3 & 1 & 8 \\
\hline $20-29$ & 31 & 9 & 3 & 43 \\
\hline $30-39$ & 42 & 7 & 6 & 55 \\
\hline $40-49$ & 20 & 3 & 2 & 25 \\
\hline $50-59$ & 6 & 3 & 0 & 9 \\
\hline$>60$ & 3 & 6 & 1 & 10 \\
\hline Total & 106 & 31 & 13 & 150 \\
\hline Percentage (\%) & 70.7 & 20.7 & 8.7 & 100 \\
\hline \multicolumn{5}{|l|}{ Marital status } \\
\hline Single & 36 & 14 & 7 & 57 \\
\hline Married & 65 & 15 & 5 & 85 \\
\hline Divorced & 0 & 0 & 1 & 1 \\
\hline Separated & 1 & 1 & 0 & 2 \\
\hline Widowed & 4 & 1 & 0 & 5 \\
\hline Total & 106 & 31 & 13 & 150 \\
\hline Percentage (\%) & 70.7 & 20.7 & 8.7 & 100 \\
\hline \multicolumn{5}{|l|}{ Main occupation } \\
\hline None & 23 & 7 & 5 & 35 \\
\hline Farming & 4 & 1 & 0 & 5 \\
\hline Artisan & 30 & 10 & 6 & 46 \\
\hline civil servant & 14 & 3 & 1 & 18 \\
\hline private sector employee & 18 & 4 & 0 & 22 \\
\hline self employed & 14 & 5 & 1 & 20 \\
\hline Others & 3 & 1 & 0 & 4 \\
\hline Total & 106 & 31 & 13 & 150 \\
\hline Percentage (\%) & 70.7 & 20.7 & 8.7 & 100 \\
\hline \multicolumn{5}{|l|}{ Gender } \\
\hline Male & 38 & 13 & 5 & 56 \\
\hline Female & 68 & 18 & 8 & 94 \\
\hline Total & 106 & 31 & 13 & 150 \\
\hline Percentage (\%) & 70.7 & 20.7 & 8.7 & 100 \\
\hline \multicolumn{5}{|c|}{ Educational qualification } \\
\hline None & 1 & 1 & 0 & 2 \\
\hline Quranic & 0 & 1 & 0 & 1 \\
\hline Primary & 13 & 8 & 0 & 21 \\
\hline Secondary & 43 & 14 & 7 & 64 \\
\hline post-secondary & 49 & 7 & 6 & 62 \\
\hline Total & 106 & 31 & 13 & 150 \\
\hline Percentage (\%) & 70.7 & 20.7 & 8.7 & 100 \\
\hline
\end{tabular}

The age range of majority of those who had a good attitude towards NHIS fell between 30 - 39 years; those who had a fair attitude fell between 20-29 years while those who had a poor attitude towards NHIS also fell between 30-39 years, 
though it was not statistically significant ( $p=0.081$ )- Table 4. This is similar to a study done by Azuogu et al., 2016 who indicated that more individuals in the age group 30-39 years agreed/ had the desire to enroll under NHIS than in other age groups and it was not statistically significant [42]. The relationship between the marital status and the attitude of the respondents showed that respondents who were married constituted the majority of those who had good and fair attitudes toward NHIS while those who were single constituted the majority of those who had a poor attitude towards NHIS (Table 4). This is a statistically significant relationship $(p=0.051)$. Similar findings were reported in Azuogu et al., 2016 who also found out married respondents were willing to participate in NHIS compared to their single counterparts [42]. There is no statistically significant relationship between the occupation and the attitude of the respondents $(p=$ 0.867) - Table 4. However, it was demonstrated that Artisans constituted the majority of those with good attitude towards NHIS, as well as fair and poor attitude. Artisans however, formed the major part of interviewed respondents. The poor attitude of artisans in our study population is in consonance with a study done by Campbell, Owoka and Odugbemi (2016) who showed that that the overall attitude of Artisans was negative towards the scheme [27].

From our study, there is no significant relationship between gender and attitude ( $p=0.824)$, as well as educational qualification and attitude $((p=0.083)$ - Table 4 ; Respondents with post-secondary qualification however constituted the majority of those who had good and fair attitude to the NHIS). This is not in keeping with studies done by Azuogu et al., 2016 and Oriakhi and Onemolease, 2012 which illustrated that males were more willing to participate in NHIS [42, 43] as well as a research carried out by Azuogu et al., 2016 which showed that majority of the respondents (49.5\%) who were willing to participate in NHIS were respondents who had Secondary school qualification followed by those who had Post- secondary qualification (34.4\%) [42].

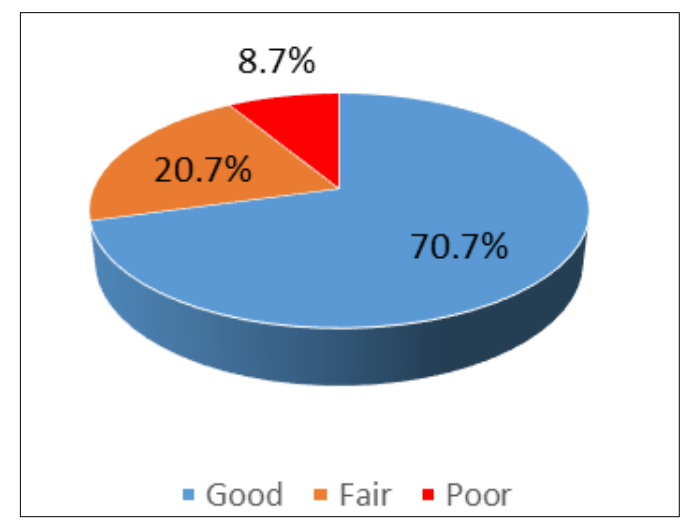

Figure 4 Attitude of the respondents to the NHIS

\subsection{Practice}

From the study, $13.3 \%$ of the index population are registered with NHIS. $30 \%$ of these were enrolled between $1-5$ years ago and $70 \%$ enrolled more than 5 years (Figure 6). This shows that there is no much progress in the NHIS coverage so far. Although Nigeria's National Health Insurance Scheme was established in 1999 to ensure health insurance coverage for the general population, very few people have registered [32].

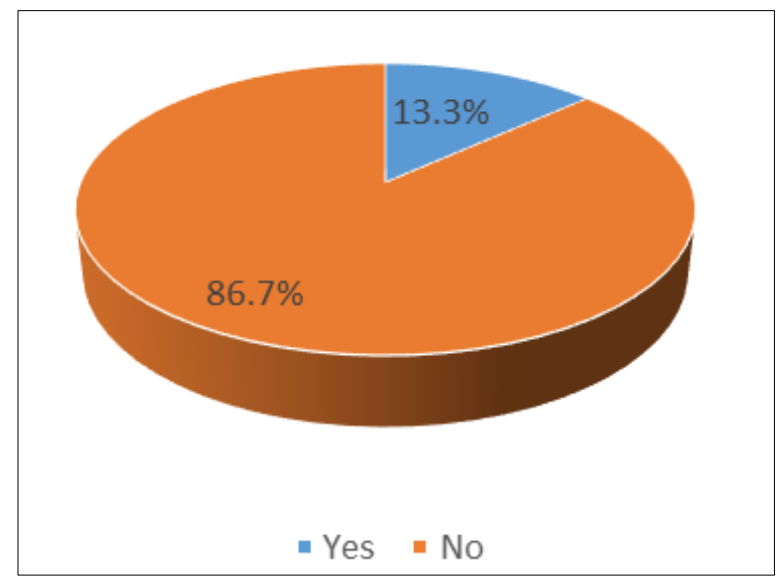

Figure 5 Registered beneficiaries of NHIS in Unguwar soya 
A 2017 report in United States showed the uninsured rates for adults in poverty and not in poverty were 25.7 percent and 10.5 percent, respectively, which is different from what is obtainable in Nigeria [44].

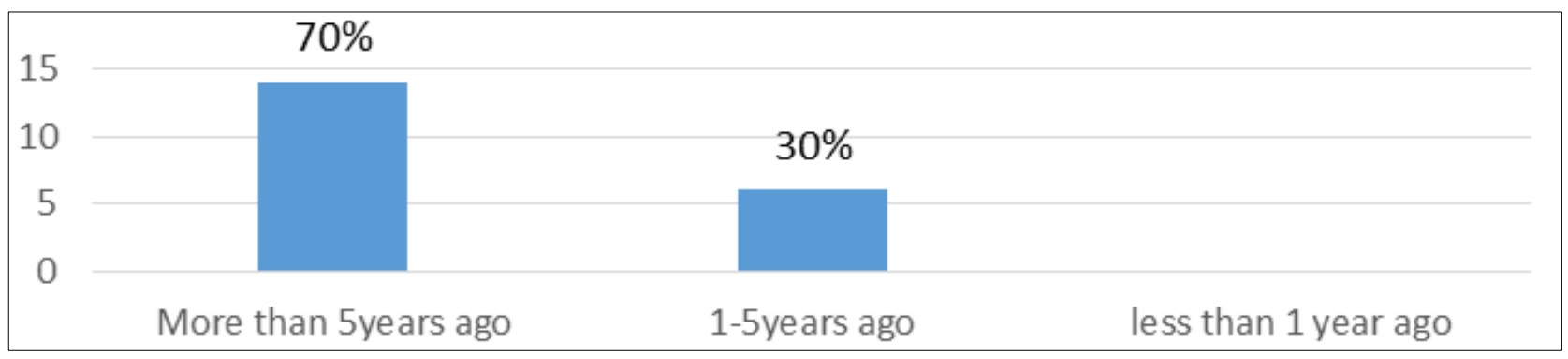

Figure 6 Duration of NHIS participation of respondents in Unguwar soya

\section{Conclusion}

Our study has showed that $59.5 \%$ of the respondents had heard about NHIIS; family and friends were the most common sources of NHIS awareness (25.5\%), followed by Television, Hospital/ Health worker and Radio making up 20.2\%, $17.4 \%$ and $16.2 \%$ respectively. Majority of the respondents (49.3\%) had heard about NHIS more than five years ago. Age, Educational status and Occupation were observed to affect the level of awareness. Majority of the respondents (70.7\%) had good attitude towards NHIS, $20.67 \%$ had fair attitude and $8.67 \%$ had poor attitude. Respondents aged 30 39 years, married people, females and respondents with post-secondary educational qualification had good attitude towards NHIS, however only the attitude of married respondents was statistically significant. Only $13.3 \%$ of the respondents are registered with NHIS. $88.5 \%$ of the respondents fund their health expenditures through Out-of-pocket payment.

\section{Recommendations}

Government and stake-holders should target artisans, low income earners, non- civil servants, traders, farmers, etc, preferably through their unions; to cover up the apparent knowledge gap amongst persons of this socio-demographic stratum and accelerate efforts to incorporate members of the community in the NHIS.

\section{Compliance with ethical standards}

\section{Acknowledgments}

Authors wish to acknowledge the Mai Angwa of Unguwar soya settlement and the Ward Head of the Kabong Ward of Jos North LGA, Plateau state, Nigeria for their gracious permission to conduct this research work in their domain. We also wish to appreciate the Associate Professor Haroun Isa, the Head of Department, Community Medicine and Primary Health Care, College of Medicine, Bingham University, Jos Nigeria for his unrelenting mentorship.

\section{Disclosure of conflict of interest}

Authors hereby declare no conflict of interest.

\section{Statement of ethical approval}

Ethical approval with reference number: NHREC/211/05/2005/00655 was obtained from the Ethical Committee of the Bingham University Teaching Hospital, Jos Nigeria, while verbal approval was obtained from the Mai Angwa of Unguwan Soya.

\section{Statement of informed consent}

Informed written consent was obtained from each respondent prior to administration of questionnaire. 


\section{References}

[1] Tanimola MA, Owoyemi J. Healthcare Seeking Behaviour in Anyigba, North Central Nigeria. Mendell Publishing. Research Journal of Medical Science. 2009; 3(2): 47-51.

[2] Lucas AO, Gilles HM. Short Textbook of Public Health Medicine for the Tropics. $4^{\text {th }}$ Edition. CRS press. 2004.

[3] Akpomwie OB. Poverty, Access to Healthcare Services and Human Capital Development in Nigeria. African Research Review. 2010; 4(3a): 41-45.

[4] Dogo-Muhammad M. The National Health Conference. Achieving the $4^{\text {th }}$ and $5^{\text {th }}$ MDGs in Nigeria: the NHIS-MDG MCH project. 2013.

[5] Sambo MN, Ejembi C, Adamu Y. Out-of-Pocket Health Expenditure for Under-five Illnesses in a Semi-urban Community in Northern Nigeria. Journal of Community and Primary Health Care. 2004; 16(1): 1.

[6] Otoyemi OD. Orthodontics in Nigeria: Journey so far and Challenges Ahead. Journal of Orthodontics. 2008; 28: 9092.

[7] Joseph AE, Philip DR. Accessibility and Utilization: Geographical Perspectives on Health care Delivery. London: Harper and Row. 1984.

[8] Eboh A, Akpata G, Akpata O, Akintoye A. Healthcare Financing in Nigeria: An Assessment of the National Health Insurance Scheme (NHIS). European Journal of Business and Management. 2017; 8(27).

[9] Williams SJ, Torrens PR. Introduction to Health Services. 7th Edition. Thomson Delmar. USA. 2008; 76-77

[10] Sofoluwe G.O, Schram R, Ogunmekan D.A. Principles and Practice of Public Health in Africa. $1998 ; 2: 866$.

[11] Yunusa U, Irinoye O, Suberu A, et al. Trends and Challenges of Public Healthcare Financing System In Nigeria: The Way Forward. Journal of Economics and Finance. 2014; 4(3): 28-34.

[12] Dotta A, Charles H. Scaling up National Health Insurance in Nigeria: Learning from case studies of India, Colombia and Thailand. Future Group, Health Policy Project. 2013; 13-14.

[13] Obansa SAJ, Orimasan A. Health Care Financing in Nigeria: Prospects and Challenges. N. Mediterranean Journal of Social Sciences. 2013; 4(1): 21-36.

[14] Adeniji FO. National Health Insurance Scheme in Nigeria; Progress towards Universal Coverage. Asian Journal of Medicine and Health. 2017. 3(4): 1-2.

[15] Mohammed AS. Nigeria: National Health Insurance Scheme and Matters Arising. Daily Trust. Abuja. 2017.

[16] UNESCO. Morbidity and Mortality Review, UNICEF, New York. 2006.

[17] Ijadunola K.T. Free Health Services in Nigeria: How Beneficial to the Poor. 2013.

[18] Wollum A, Bursten R, Fullman N, Dwyer-Lindgren L, Gaidou E. Benchmarking Health System Performance across states in Nigeria: A Systematic Analysis of Levels and Trends in Key aternal and Child Health Interventions and Outcomes, 2000 - 2013. BMC Medicine; 2015; 13: 208.

[19] UNICEF and WHO. Countdown to 2015: A Decade of Tracking Progress for Maternal, Newborn and Child Survival. 2015.

[20] Onwujekwe 0, Hanson K, Uzochukwu B. Examining Inequities in Incidence of Catastrophic Helath Expenditure on Different Healthcare Sources and Health Facilities in Nigeria. PCOS One. 2012; 7: e40811.

[21] Raji B.A, Oladele O.A, Akolokwu G.O, Tanimu A. Health Status of Seniour Citizens vizs-a-vis The National Health Insurance Scheme of Nigeria. NAUJILJ. 2019; 10(1): 176-182.

[22] Abdulraheem IS, Olapipo AR, Aodu MO. PHC Services in Nigeria: Critical Issues and Strategies for Enhancing the Use by the Rural Communities. Journal of Public Health and Epidemiology. 2012; 4: 5-13.

[23] Emmanuel NK, Gladys EN, Cosmas UU. Consumer Knowledge and Availabilit of Maternal and Child Health Services: A Challenge for Achieving MDG 4,5 in South-East Nigeria; BMC Health Service Resource. 2013; $13: 53$.

[24] Riman HB, Akpan ES. Heath Care Financing and Health Outcomes in Nigeria. A state Level Study using Multivariate Analysis. International Journal of Humanities and Social Sciences. 2012; 2: 296 - 309. 
[25] Lawanson A0, Olaniyan 0, Soyibo A. National Health Account Estimate: Lessons from the Nigerian Experience; African Journal of Medicine and Medical Sciences. 2012; 41: 357 - 364.

[26] National Health Insurance Scheme Decree No. 35 of 1999. Laws if the Federaton of Nigeira. Nigeria Law.

[27] Campbell P.C, Owoka O.M, Odugbemi T.O. National Health Insurance Scheme (NHIS): Are the Artisans Benefitting in Lagos state, Nigeria? J ClinSci. 2016; 13: 122-31.

[28] Onyedibe IK, Goyat GM, Nnadi NE. An Evaluation of the National Health Insurance Scheme in Jos, a North-Central Nigerian City. Global Advanced Research Journal of Microbiology. 2012; 1(1): 005 - 012.

[29] Colton T. Statistics in Medicine. Lippincott Wiliams \& Wilkins, a Walter Kluwer Company. 1974.

[30] Abah M.U, Adeola V.O, Chiroma H.T, Ayendele I. An Evaluation of Routine Immunization Status of Children Less than Five (5) Years in Unguwar Soya, Jos, Plateau State, Nigeria. Bingham Uniersity Library. 2019; 26.

[31] Ekwuluo CE, Eluwa AN, Okereke IC, Orji SB. Knowledge, Attitude to, and Utilization of the National Health Insurance Scheme (NHIS) Among Health Workers in the University of Nigeria Teaching Hospital (UNTH), ItukuOzalla, Enugu State, Nigeria. Int'l Journal of Research - Granthaalayah. 2018; 6(1): 13 - 14.

[32] National population commission Federal Republic of Nigeria. Demographic and health survey. Abuja, Nigeria. 2013; 18: 33-50.

[33] Labour force statistics.Unemployment and underemployment report. 2018; 1: 28.

[34] Annual collaborative survey of socio-economic activities in Nigeria. 2006; 1: 9-15.

[35] Sanusi R, Awe AT. Assessment of Awareness Level of National Helath Insurance Scheme Among Health Care Consumers in Oyo State, Nigeria. JOUR. 2009; 143-148.

[36] Eyong AK, Ayada PO, Asukwo EO, Irene C. Awareness of National Helath Insurance Scheme and Quality of Helath Care Services among Civil Servants in Cross River State, Nigeria. Research on Humanities and Social Sciences. 2016; 6(13): 1-10.

[37] Olugbenga-Bello AI, Adebimpe WO. Knowledge and Attitude of Civil Servants in Osun State, Southwestern Nigeria towards the National Health Insurance. Niger J ClinPract. 2010; 13: 421-6.

[38] Oladimeji 0, Alabi A, Adeniyi 00. Awareness, knowledge and Participation of the National Health Insurance Scheme among Helath Professionals in the Mthatha General Hospital, Eastern Cape, South Africa. Benthan Open. 2017; 10: 187-194.

[39] Adibe M, Udeogaranya PO, Ubaka C. Awareness of National Health Insurance Scheme Activities among Employees of A Nigerian University. Int. J. Drug Dev. \& Res. 2011; 3(4): 78-85.

[40] Ibiwoye A, Adeleke IA. Does National Helath Insurance Promote Access to Quality Health Care? Evidence form Nigeria. 2008; 33(2): 219-233.

[41] Adewole DA, Adebayo MA, Udeh EI, Shaahu NV, Dairo MD. Payment for Health Care and Perception of the National Health Insurance Scheme in a Rural Area in Southwest Nigeria, Am J Trop Med Hyg. 2015; 93(3): 648.

[42] Azuogu BN, Madubueze UC, Alo C, Ogbonnaya L.U, Ajayi N.A. Level of Awareness and Factors Associated with Willingness to Participate in the National Health Insurance Scheme among Traders in Abakiliki Main Market. African Journal of Medical and Health Sciences. 2016; 15 (1): 18-23.

[43] Oriakhi H.O and Onemolease E.A. Determinants of Rural Household's Willingness to Participate in Community Based Health Insurance Scheme in Edo State, Nigeria. 2012; 6(2): 99

[44] Edward RB, Emily H and Jessica C B. Health insurance coverage in the United States. 2017; 16. 